\title{
Air Emissions of Sulphur Dioxide From Gasoline and Diesel Consumption in the Southwestern States of Nigeria
}

\author{
S. O. Olatunji, ${ }^{1}$ B. S. Fakinle, ${ }^{1}$ L. A. Jimoda, ${ }^{2}$ J. A. Adeniran, ${ }^{3}$ and A. J. Adesanmi ${ }^{1}$ \\ ${ }^{1}$ Environmental Research Laboratory, Department of Chemical Engineering, Obafemi Awolowo \\ University, Ile-Ife, Nigeria \\ ${ }^{2}$ Department of Chemical Engineering, Ladoke Akintola University, Ogbomoso, Nigeria \\ ${ }^{3}$ Environmental Research Laboratory, Department of Chemical Engineering, University of Ilorin, \\ Ilorin, Nigeria
}

\begin{abstract}
The contribution of $\mathrm{SO}_{2}$ emissions from the consumption of petroleum products to Nigerian airshed has been of great concern over the years because of the resulting adverse environmental and health effects. It is in the light of this that air emissions of $\mathrm{SO}_{2}$ from gasoline and diesel consumed in the Southwestern States of Nigeria were estimated in this study. Lagos state being the highest consumer of gasoline and diesel in Southwestern Nigeria emitted the highest quantity.
\end{abstract}

Keywords: diesel, gasoline, Nigeria, sulphur dioxide

\section{INTRODUCTION}

Persistent unsolved epileptic power supply and the growing economy have led to increase in the rate of petroleum products consumption in Nigeria (Adenikinju, 2003). The air emissions of sulphur dioxide $\left(\mathrm{SO}_{2}\right)$ and its environmental and health impacts from the consumption of refined petroleum products with nonuniformity in sulphur contents in Nigeria could be mitigated, provided there is proper and consistence investigation. Significant amounts of $\mathrm{SO}_{2}$ particles have been released to the air globally, due to combustion characteristics of various engines and a widespread use of fuels with nonuniform qualities in terms of sulphur levels (Kasper et al., 2007). Sulphur is chemically bonded to the hydrocarbons of the fuel and during combustion; most suphur is oxidized to $\mathrm{SO}_{2}(\mathrm{MAN} \mathrm{B \& W}$ Diesel, 1996). Sulphur, which is mostly oxidized to $\mathrm{SO}_{2}$ during combustion, is a major constituent of the primary particles in the exhaust from gasoline and diesel powered engines from the combustion of fuel (Kasper et al., 2007; Agrawal et al., 2008; Petzold et al., 2008; Moldanová et al., 2009; Popovicheva et al., 2009). Sulphate particles in the exhaust system form during the cooling of the exhausts and a reaction between $\mathrm{SO}_{3}$ and water, which forms $\mathrm{H}_{2} \mathrm{SO}_{4}$. Kasper et al. (2007) found that $1.4 \%$ of the sulphur in the fuel was in the form of sulphate in exhaust gas particles. Agrawal et al. (2008) showed a sulphate particle formation between $7 \%$ and $5 \%$ for the same mechanisms during exhaust gas measurements after dilution with air, while Moldanová et al. (2009) concluded on $1.3 \%$. Endresen et al. (2003) estimated that approximately half of the amount of emitted $\mathrm{SO}_{2}$ from fuel combustion was deposited mainly by dry deposition. The two different pathways for

Address correspondence to B. S. Fakinle, Environmental Research Laboratory, Department of Chemical Engineering, Obafemi Awolowo University, Ile-Ife, Nigeria. E-mail: xdales@yahoo.com

Color versions of one or more of the figures in the article can be found online at www.tandfonline.com/lpet. 


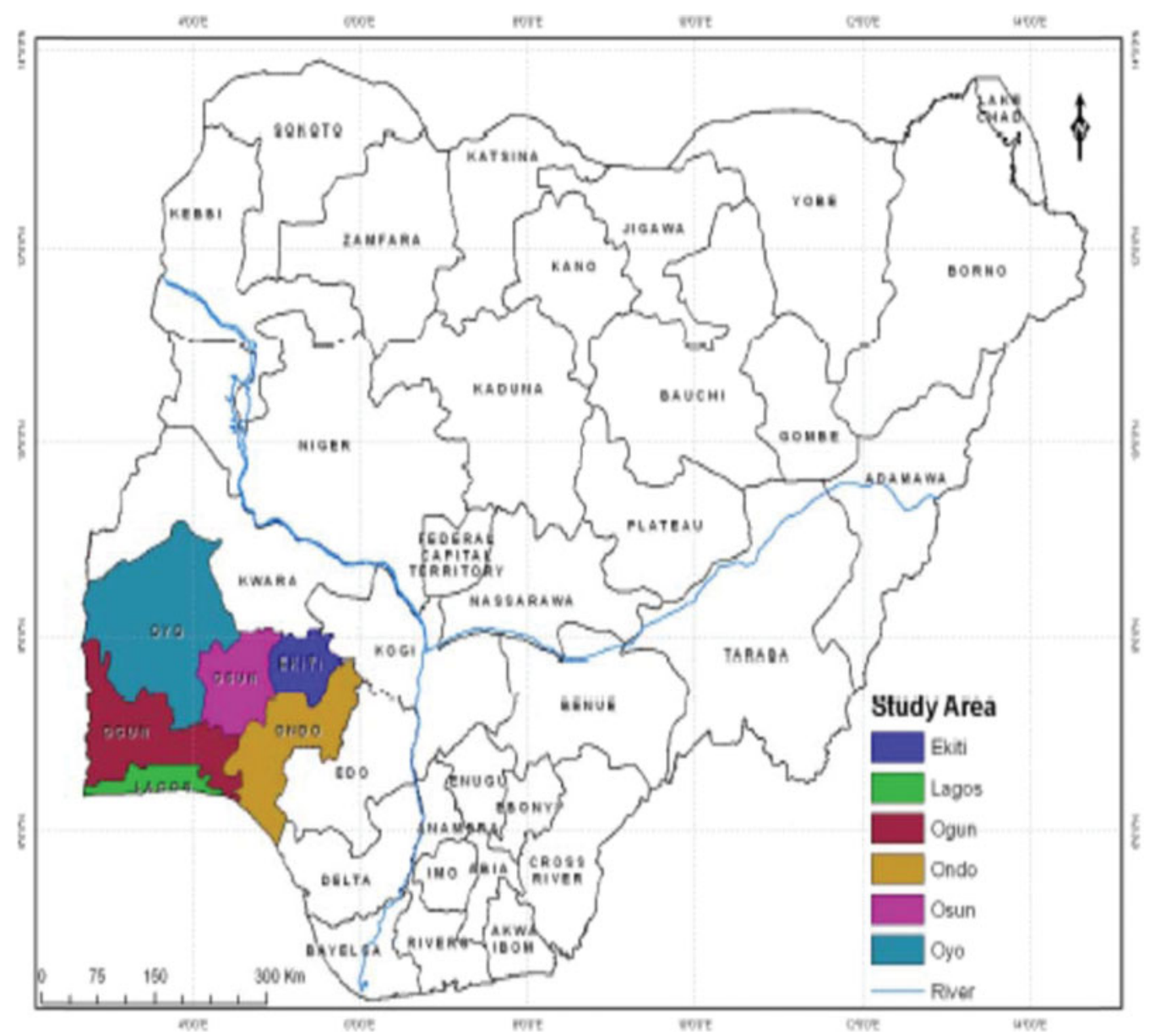

FIGURE 1 The study areas in Nigeria.

$\mathrm{H}_{2} \mathrm{SO}_{4}$ formation are either gaseous $\mathrm{SO}_{2}$ reacts with hydroxyl radical molecules $(\cdot \mathrm{OH})$, or it reacts heterogeneously in the liquid phase or on surfaces (Finlayson-Pitts and Pitts, 2000).

The main environmental concerns related to $\mathrm{SO}_{2}$ emissions are acid rain and the formation of particulate matter (PM). Acid rain has many negative environmental impacts, which include the acidification of aquatic systems, increase in soil acidity, and damage to vegetation (Schmidt, 2006). Acid rain can also cause the degradation of buildings and other human infrastructure (U.S. Environmental Protection Agency, 1998). The PM emissions result in reduced visibility and also have impacts on human health. The Human health impacts of PM are generally related to respiratory illnesses, including increased frequency in bronchitis and asthma. These illnesses have led to an increase in premature mortality (Schmidt, 2006).

Several manual and continuous analytical techniques are used to measure $\mathrm{SO}_{2}$ in the atmosphere. The manual techniques involve two-stage sample collection and measurement (Vallero, 2008). The West-Gaeke manual method is the basis for the U.S. Environmental Protection Agency (USEPA) reference method for measurement of $\mathrm{SO}_{2}$ (Stern et al., 1994). Other methods such as emission factor and mass balance have been widely reported in earlier studies (Obioh et al., 1994: Sonibare and Akeredolu, 2006). The annual average global $\mathrm{SO}_{2}$ emission was estimated to be 1,561,100 


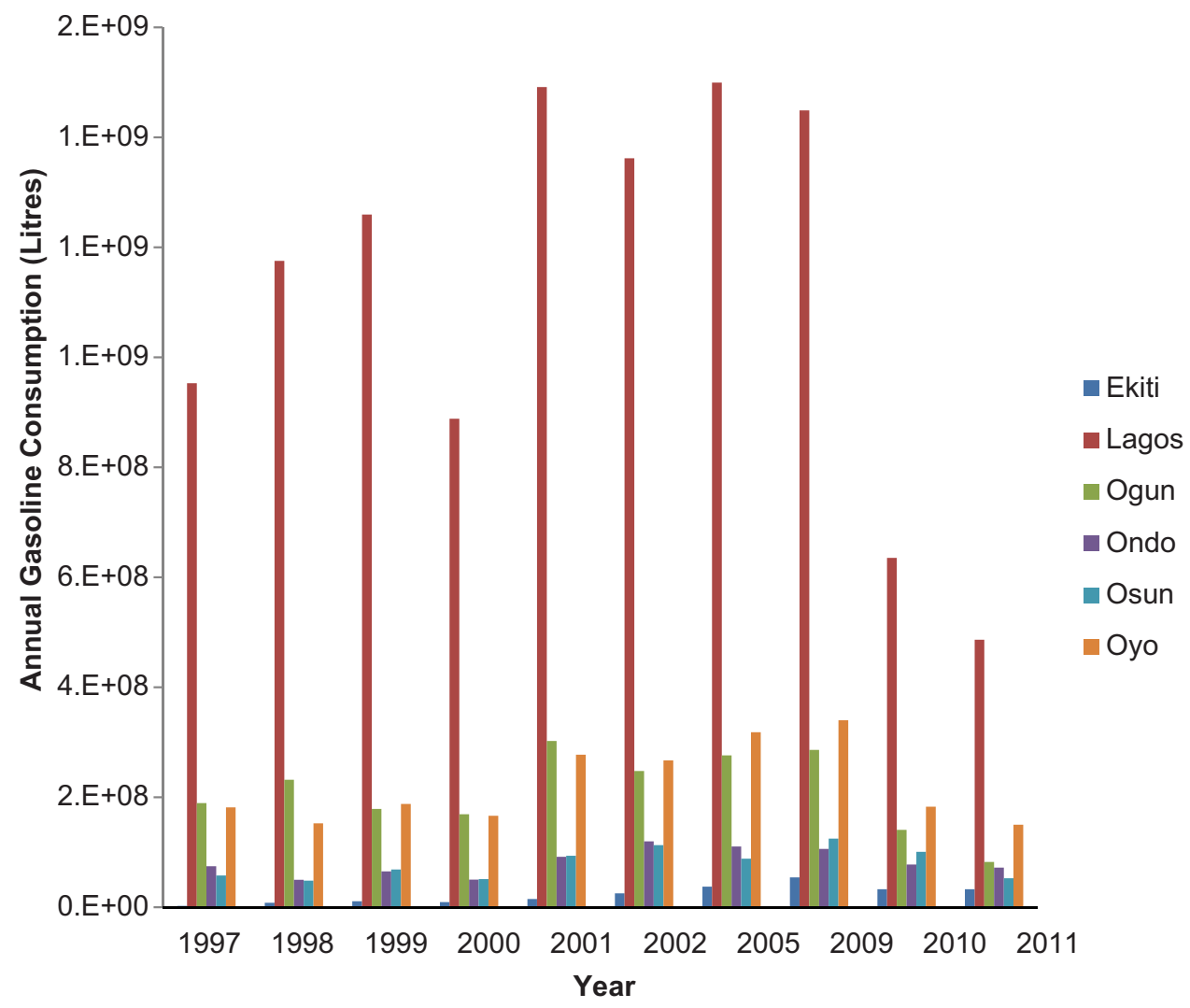

FIGURE 2 Gasoline consumption in the six states of Southwestern Nigeria for 10 selected years.

tons $/ \mathrm{km}^{2}$ and annual $\mathrm{SO}_{2}$ emission of 190,000 tons $/ \mathrm{km}^{2}$ for Nigeria (Intergovernmental Panel on Climate Change, 2005). Obioh et al. (1994) reported the annual $\mathrm{SO}_{2}$ emission of 85,920 tons/year for Nigeria. The contribution of $\mathrm{SO}_{2}$ emissions from the consumption of refined petroleum products to the national and global $\mathrm{SO}_{2}$ emission levels has been a threat over the years because of the resulting adverse environmental and health effects. It is with this view that the air emissions of $\mathrm{SO}_{2}$ from gasoline and diesel consumption in the Southwestern states of Nigeria were investigated in this study for 10 selected years.

\section{METHODOLOGY}

\subsection{Study Area}

The six Southwestern states in Nigeria are Lagos, Ogun, Oyo, Osun, Ondo, and Ekiti. Lagos state is located between $6^{\circ} 35^{\prime} \mathrm{N}$ and $3^{\circ} 45^{\prime} \mathrm{E}$. Although Lagos state is the smallest state in Nigeria, with an area of $3,671 \mathrm{~km}^{2}$, yet it has the second highest population of 9,113,605. Osun state is an inland state with a population of $3,416,959$, land area of $9,026 \mathrm{~km}^{2}$ and located between $7^{\circ} 30^{\prime} \mathrm{N}$ and $4^{\circ} 30^{\prime} \mathrm{E}$. Oyo state is located between $8^{\circ} 00^{\prime} \mathrm{N}$ and $4^{\circ} 00^{\prime} \mathrm{E}$ with land area of $9,026 \mathrm{~km}^{2}$ and population of 5,580,894. Ogun state has a population of $3,751,140$ with a land area of $16,400 \mathrm{~km}^{2}$ 


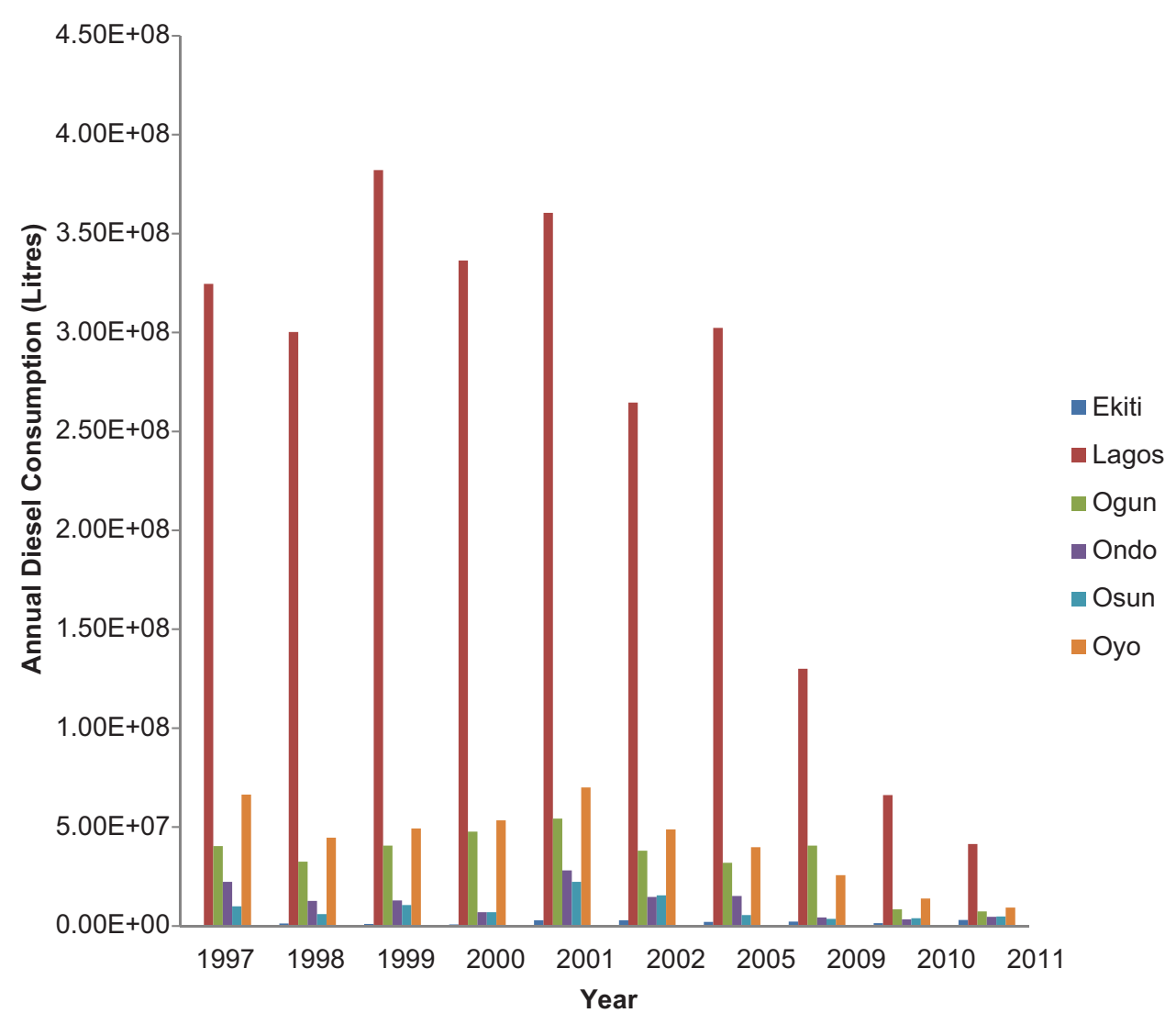

FIGURE 3 Diesel consumption in the six states of Southwestern Nigeria for 10 selected years.

located between $7^{\circ} 00^{\prime} \mathrm{N}$ and $3^{\circ} 35^{\prime} \mathrm{E}$. Ondo state is located between $7^{\circ} 10^{\prime} \mathrm{N}$ and $5^{\circ} 05^{\prime} \mathrm{E}$ with a population of $3,460,877$ and land area of $15,820 \mathrm{~km}^{2}$. Ekiti state has land area of $5,435 \mathrm{~km}^{2}$ with a population of $2,398,957$ located between $7^{\circ} 40^{\prime} \mathrm{N}$ and $5^{\circ} 15^{\prime} \mathrm{E}$ (NBS, 2010). Southwestern Nigeria receives the highest percentage of $41 \%$ out of the total volume of refined petroleum products distributed across the country annually (Nigerian National Petroleum Corporation, 2011). Figure 1 shows the study areas in Nigeria.

\subsection{Estimation of Sulphur Dioxide Emission}

The annual $\mathrm{SO}_{2}$ emission from consumption of refined petroleum products was estimated using a combination of annual domestic consumption of refined petroleum products data from Nigerian National Petroleum Corporation annual statistical bulletin (Figures 2 and 3) and an uncontrolled emission factor approach (National Bureau of Statistics, 2010). Table 1 shows emission factors for $\mathrm{SO}_{2}$ in uncontrolled gasoline and diesel engines used in the study. It was generally assumed in this study that the sulphur content of the fuel was constant for the 10 selected years. The average sulphur content of gasoline and diesel from southwestern states in Nigeria is presented in Table 2. The average densities of the gasoline and diesel fuel considered in this study are $0.739 \mathrm{~kg} / \mathrm{L}$ and $0.844 \mathrm{~kg} / \mathrm{L}$, respectively. The total annual emissions of sulphur dioxide from gasoline and diesel 
TABLE 1

Emission Factors for $\mathrm{SO}_{2}$ in Uncontrolled Gasoline and Diesel Engines

\begin{tabular}{lcc} 
& & Fuel Input \\
\cline { 2 - 3 } Fuel & lb/MMBtu $^{a}$ & $g / L^{b}$ \\
\hline Gasoline & 0.084 & 1.26 \\
Diesel & 0.29 & 4.72 \\
\hline
\end{tabular}

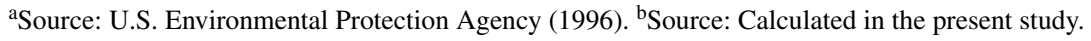

consumption in the Southwestern Nigeria were calculated by summing the annual average sulphur dioxide emissions of all its six states.

The general equation used for estimating the annual uncontrolled emissions of $\mathrm{SO}_{2}$ from gasoline and diesel consumption is given in Eq. (1).

$$
\text { Annual } \mathrm{SO}_{2} \text { Emission }=\text { Annual fuel Consumption } *(\text { Emission Factor } * \text { Sulphur Content })
$$

\section{RESULTS AND DISCUSSION}

The results of the annual $\mathrm{SO}_{2}$ emissions from gasoline and diesel consumed in the six Southwestern States of Nigeria and the total annual $\mathrm{SO}_{2}$ emissions in Southwestern region are presented in Tables 3 and 4 respectively. The highest $\mathrm{SO}_{2}$ emission of 0.928 tons/year was obtained in 2009 due to the volume of gasoline consumed in the year, while the lowest $\mathrm{SO}_{2}$ emission of 0.045 tons/year was recorded in 1997 from Ekiti state. Annual $\mathrm{SO}_{2}$ emission from diesel consumed in Ekiti state was at its peak in 2011 with 1.503 tons/year and was at minimal level of 0.262 tons/year in 1997 .

The respective maximum and minimum annual $\mathrm{SO}_{2}$ emissions of 26.91 tons/year and 0.734 tons/year from gasoline consumption in Lagos state were experienced in 2005 and 2011. The lowest $\mathrm{SO}_{2}$ emission of 19.39 tons/year was recorded in 2011 while the highest $\mathrm{SO}_{2}$ emission of 179 tons/year was obtained in 2001 from diesel consumed in Lagos state. The highest quantity of $\mathrm{SO}_{2}$ is emitted from gasoline and diesel consumed in Lagos state when compared to other states of Southwestern Nigeria as result of the population and high rate of petroleum products consumption in the state.

In Ogun state, annual $\mathrm{SO}_{2}$ emission from gasoline consumption was at its peak in 2001 with 3.318 tons/year and was at minimal level of 0.904 tons/year in 2011. The maximum and minimum annual $\mathrm{SO}_{2}$ emissions of 24.77 tons/year and 3.367 tons/year from diesel consumption in Ogun state

TABLE 2

Average Sulphur Content of Gasoline and Diesel From Southwestern States in Nigeria

\begin{tabular}{lccc}
\hline $\begin{array}{l}\text { Gasoline Sample } \\
\text { Location }\end{array}$ & $\begin{array}{l}\text { Average Sulphur Content, } \\
w t \%\end{array}$ & $\begin{array}{l}\text { Diesel Sample } \\
\text { Location }\end{array}$ & $\begin{array}{l}\text { Average Sulphur Content, } \\
\text { wt\% }\end{array}$ \\
\hline Osun State & 0.0063 & Osun State & 0.101 \\
Oyo State & 0.0134 & Oyo State & 0.090 \\
Ogun State & 0.0087 & Ogun State & 0.097 \\
Lagos State & 0.0142 & Lagos State & 0.099 \\
Ekiti State & 0.0136 & Ekiti State & 0.107 \\
Ondo State & 0.0076 & Ondo State & 0.091 \\
\hline
\end{tabular}


TABLE 3

Total Annual Emission of Sulphur Dioxide from Gasoline Consumption in Southwestern Nigeria

\begin{tabular}{llllllll}
\hline \multicolumn{7}{c}{ Average Emission of SO $_{2}$, tons/annum } \\
\hline Year & Ekiti & Lagos & Ogun & Ondo & Osun & Oyo & SW \\
\hline 1997 & 0.045 & 17.1 & 2.08 & 0.739 & 0.456 & 2.852 & 23.27 \\
1998 & 0.142 & 21.1 & 2.547 & 0.496 & 0.384 & 2.396 & 27.07 \\
1999 & 0.186 & 22.61 & 1.964 & 0.647 & 0.542 & 2.95 & 28.9 \\
2000 & 0.159 & 15.94 & 1.856 & 0.497 & 0.405 & 2.613 & 21.47 \\
2001 & 0.254 & 26.77 & 3.318 & 0.908 & 0.741 & 4.361 & 36.35 \\
2002 & 0.43 & 24.44 & 2.721 & 1.187 & 0.893 & 4.197 & 33.87 \\
2005 & 0.642 & 26.91 & 3.033 & 1.094 & 0.697 & 5.001 & 37.38 \\
2009 & 0.928 & 26.01 & 3.143 & 1.051 & 0.987 & 5.343 & 37.46 \\
2010 & 0.558 & 11.4 & 1.547 & 0.768 & 0.796 & 2.876 & 17.95 \\
2011 & 0.561 & 8.734 & 0.904 & 0.714 & 0.416 & 2.358 & 13.69 \\
\hline
\end{tabular}

were obtained in 2001 and 2011, respectively. The minimum value recorded in 2011 was as result of inaccurate reported data for the annual petroleum products consumed in the year (Nigerian National Petroleum Corporation, 2011).

The highest $\mathrm{SO}_{2}$ emission of 1.187 tons/year was obtained in 2002 while the lowest $\mathrm{SO}_{2}$ emission of 0.496 tons/year was recorded in 1998 from Ondo state. The lowest $\mathrm{SO}_{2}$ emission of 1.445 tons/year was recorded in 2010 while the highest $\mathrm{SO}_{2}$ emission of 12.03 tons/year was obtained in 2001 from diesel consumed in Ondo state due to the volume of gasoline consumed in the year.

In Osun state, the quantity of $\mathrm{SO}_{2}$ emitted from gasoline and diesel consumed reached maximum levels of 0.987 tons/year and 10.62 tons/y in 2009 and 2001, respectively, while it attained respective minimum values of 0.384 tons/year and 1.687 tons/year in 1998 and 2009, respectively.

Oyo state, which is the second highest $\mathrm{SO}_{2}$ emitter in Southwestern Nigeria due to its high population and high rate of petroleum product consumption, released as high as 5.343 tons/year and 29.75 tons/year of $\mathrm{SO}_{2}$ from gasoline and diesel consumed in 2009 and 2001, respectively. Also, the lowest $\mathrm{SO}_{2}$ emissions of 2.358 tons/year and 3.946 tons/year from gasoline and diesel consumed were respectively obtained from the state in 2011.

In Tables 3 and 4, the total annual $\mathrm{SO}_{2}$ emissions from gasoline and diesel were respectively at the peak in 2001 and 2009 and at the lowest levels in 2011. As constant sulphur content was assumed

TABLE 4

Total Annual Emission of Sulphur Dioxide from Diesel Consumption in Southwestern Nigeria

\begin{tabular}{llllllll}
\hline \multicolumn{7}{c}{ Average Emission of SO $_{2}$, tons/annum } \\
\hline Year & Ekiti & Lagos & Ogun & Ondo & Osun & Oyo & SW \\
\hline 1997 & 0.262 & 152.1 & 18.42 & 9.559 & 4.717 & 28.23 & 213.3 \\
1998 & 0.639 & 140.6 & 14.84 & 5.405 & 2.839 & 18.98 & 183.3 \\
1999 & 0.515 & 179 & 18.53 & 5.529 & 5.033 & 20.95 & 229.6 \\
2000 & 0.381 & 157.6 & 21.75 & 2.979 & 3.31 & 22.7 & 208.7 \\
2001 & 1.43 & 168.9 & 24.77 & 12.03 & 10.62 & 29.75 & 247.5 \\
2002 & 1.43 & 124 & 17.37 & 6.267 & 7.377 & 20.74 & 177.2 \\
2005 & 1.049 & 141.6 & 14.58 & 6.467 & 2.624 & 16.92 & 183.2 \\
2009 & 1.114 & 60.89 & 18.53 & 1.825 & 1.689 & 10.9 & 94.95 \\
2010 & 0.693 & 31 & 3.851 & 1.445 & 1.874 & 5.897 & 44.76 \\
2011 & 1.503 & 19.39 & 3.367 & 1.963 & 2.28 & 3.946 & 32.45 \\
\hline
\end{tabular}


for the selected years in this study for each of the six states in Southwestern Nigeria, several factors (e.g., population, economic boost or meltdown, and irregular power supply, which leads to increase or decrease in petroleum products consumption rate) could have affected the total $\mathrm{SO}_{2}$ emission between 1997 and 2011.

\section{CONCLUSION}

In this study air emission of sulphur dioxides from gasoline and diesel consumption in the six states of Southwestern Nigeria were investigated. The contribution of sulphur dioxide emissions from gasoline and diesel consumption in the zone to her national emission levels was also established. It was generally assumed in this study that the sulphur content of the fuel was constant for the 10 selected years between 1997 and 2011. The unavailability of data for the volume of domestic petroleum products consumption was the reason for the unselected years between 1997 and 2011.

Lagos state as the highest consumer of gasoline and diesel in Southwestern Nigeria and emitted the highest quantity of $\mathrm{SO}_{2}$ while Ekiti state had the lowest gasoline and diesel consumer and emitted the lowest quantity of $\mathrm{SO}_{2}$ in all the selected years except in 2011 when Osun state emitted the lowest quantity of $\mathrm{SO}_{2}$ from diesel consumed. The estimated total contribution of sulphur dioxide emissions from gasoline and diesel consumed in Southwestern Nigeria to the national airshed was found to be minimal.

The air emissions of sulphur dioxide $\left(\mathrm{SO}_{2}\right)$ and its environmental and health impacts from the consumption of refined petroleum products with nonuniformity in sulphur contents in Nigeria could be mitigated, provided there is proper and consistence investigation. The study concluded that to mitigate the air emissions of sulphur dioxide, a cleaner technology control approach should be adopted in the form of fuel modification or fuel change since sulphur dioxide emissions are proportional to the sulphur contents of the fuel, the use of low or near-zero sulphur fuel must be imposed.

\section{REFERENCES}

Adenikinju, A. F. (2003). Electricity infrastructure failures in Nigeria: a survey-based analysis of the costs and adjustments responses. Energy Policy 31:1519-1530.

Agrawal, H., Malloy, Q. G. J., Welch, W. A., Miller, J. W., and Cocker, D. R. (2008). In-use gaseous and particulate matter emissions from a modern ocean going container vessel. Atmos. Environ. 42:5504-5510.

Endresen, Ø., Sørgård, E., Behrens, H. L., Brett, P. O., and Isaksen, I. S. A. (2007). A historical reconstruction of ships' fuel consumption and emissions. Journal of Geophysical Research: Atmospheres 112:D12301.

Finlayson-Pitts, B. J., and Pitts, J. N. (2000). Chemistry of the upper and lower atmosphere. New York: Academic Press.

Intergovernmental Panel on Climate Change. (2005). $\mathrm{SO}_{2}$ emission per populated area by country. Special Report on Emissions Scenarios, Data version 1.1. Available at: www.nationmaster.com/country-info/stats/Environment/ $\mathrm{SO} 2$-emissions-per-populated-area.

Kasper, A., Aufdenblatten, S., Forss, A., Mohr, M., and Burtscher, H. (2007). Particulate emissions from a Low-speed marine diesel engine. Aerosol Sci. Technol. 41:24-32.

MAN B\&W Diesel. (1996). Emission control: Two stroke low-speed diesel engines. Copenhagen: MAN.

Moldanová, J., Fridell, E., Popovicheva, O., Demirdjian, B., Tishkova, V., Faccinetto, A., and Focsa, C. (2009). Characterisation of particulate matter and gaseous emissions from a large ship diesel engine. Atmos. Environ. 43: 2632-2641.

National Bureau of Statistics. (2010). Annual abstract of statistics. Abuja, Nigeria: National Bureau of Statistics.

Nigerian National Petroleum Corporation. (2011). Annual statistical bulletin. Abuja, Nigeria: Nigerian National Petroleum Corporation.

Obioh, I. B., Oluwole, A. F., Akeredolu, F. A., and Asubiojo, O. I. (1994). National inventory of air pollutants in Nigeria emissions for 1988. Benin City, Benin: Ilupeju Press. 
Petzold, A., Hasselbach, J., Lauer, P., Baumann, R., Franke, K., Gurk, C., Schlager, H., and Weingartner, E. (2008). Experimental studies on particle emissions from cruising ship, their characteristic properties, transformation and atmospheric lifetime in the marine boundary layer. Atmos. Chem. Phys. 8:2387-2403.

Popovicheva, O., Kireeva, E., Shonija, N., Zubareva, N., Persiantseva, N., Tishkova, V., Demirdijan, B., Moldanová, J., and Mogilnikov, V. (2009). Ship particulate pollutants: Characterization in terms of environmental implication. J. Environ. Monit. 11:2077-2086.

Schmidt, L. (2006). Future engine fluids technologies: Durable, fuel-efficient, and emissions-friendly. 11th Diesel Engine Emissions Reduction Conference. Retrieved from http://www.eere.energy.gov/vehiclesandfuels/pdfs/deer_2005/panel1/ 2005_deer_bardasz.pdf

Sonibare, J. A., and Akeredolu, F. A. (2006). A theoretical prediction of non-methane gaseous emissions from natural gas combustion. Energy Policy 32:1653-1665.

Stern, C. A., Boubel, R. W., Fox, D. L., and Turner, D. B. (1994). Fundamentals of air pollution (3rd ed.). New York: Academic Press.

U.S. Environmental Protection Agency. (1996). AP42 emission factors. Washington, DC: U.S. Government Printing Office.

U.S. Environmental Protection Agency. (1998). 1996 Toxics release inventory, public data release: Ten years of right-to-know. EPA 745-r-98-005.

Vallero, A. D. (2008). Fundamentals of air pollution (4th ed.). New York: Academic Press. 
Copyright of Petroleum Science \& Technology is the property of Taylor \& Francis Ltd and its content may not be copied or emailed to multiple sites or posted to a listserv without the copyright holder's express written permission. However, users may print, download, or email articles for individual use. 